\title{
Arsenate Adsorption Mechanism on Nano-ball Allophane by Langmuir Adsorption Equation
}

\author{
Elvis Anup Shukla, Naoto Matsue, Teruo Henmi and Erni Johan \\ Laboratory of Applied Chemistry for Environmental Industry, Faculty of Agriculture, Ehime University, Japan
}

crossref http://dx.doi.org/10.5755/j01.erem.58.4.395

(received in June, 2011, accepted in December, 2011)

\begin{abstract}
Arsenic is considered as the synonym of death. High toxicity of arsenic in nature is a worldwide problem and often referred to as $20^{\text {th }}-21^{\text {st }}$ century calamity. High arsenic concentration has been reported recently from USA, China, Chile, Bangladesh, Taiwan, Mexico, Argentina, Poland, Canada, Hungry, Japan and India. Among all the countries Bangladesh and West Bengal of India are at the high risk. Thus arsenic disposal became an important task. In the present study an attempt is made to study the adsorption of toxic arsenic on allophanes.

The adsorption of arsenate on a low $\mathrm{Si} / \mathrm{Al}$ ratio allophane $(\mathrm{KyP})$ was found to be very effective in reducing the amount of arsenic below the toxic level. The examination of adsorption isotherm of arsenate on allophane by Langmuir theory indicated that arsenate adsorption increased with the increasing bulk solution concentration. The observed increase in the $\mathrm{pH}$ can be attributed to the ligand exchange on allophane. Aluminol groups, $\mathrm{Al}-\mathrm{OH}$ or $\mathrm{Al}-\mathrm{OH}_{2}$, on allophane are responsible for the adsorption in soil.
\end{abstract}

Keywords: Allophane, Arsenic, Adsorption, Langmuir equation, mechanism.

\section{Introduction}

Arsenic (atomic number 33) is an omnipresent substance that rank $20^{\text {th }}$ in the natural abundance comprising about $0.00005 \%$ of the earth crust, $14^{\text {th }}$ in the sea water, and $12^{\text {th }}$ in the human body (Mandal et al. 2002). The real cause of existence of arsenic still puzzles the scientists around the world. Arsenic is mobilized through the combination of various natural processes such as weathering reaction, biological activity and volcanic emissions, it also mobilize through the range of various anthropogenic activities. The environmental arsenic problems are because of its mobilization under natural condition. Leaching and soil erosion contribute to $2380 \times 10^{8}$ and $612 \times 10^{8}$ $\mathrm{g} /$ year of arsenic respectively, in dissolved and suspended forms in the ocean(Mackenzie 1979). However human activity such as mining, fossil fuel combustion, use of arsenic pesticides, herbicides, and crop desiccants and use of arsenic additives to livestock feed create more harmful impact. The arsenic use has been deeply decreased in past decades but it is still used as wood preservatives.

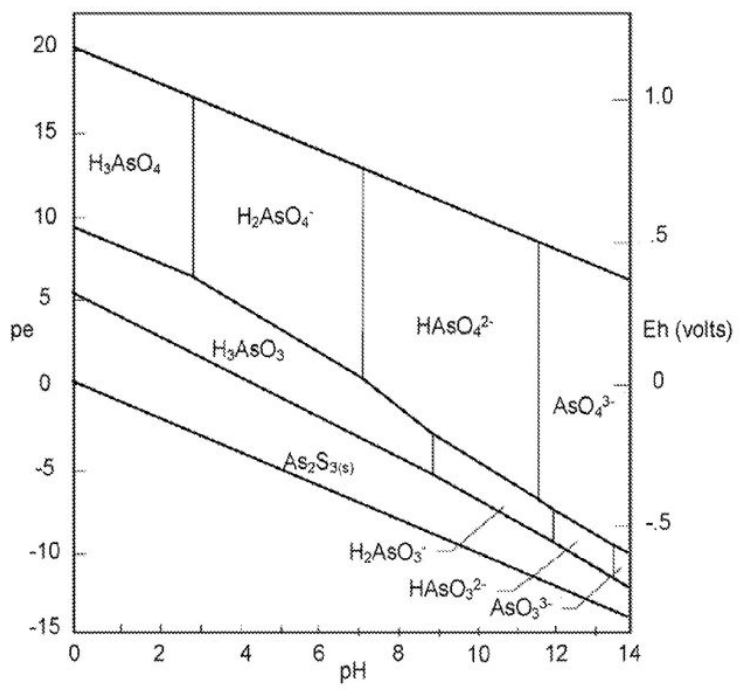

Fig.1. Eh-pH diagram for aqueous arsenic species in the system $\mathrm{As}-\mathrm{O}_{2}-\mathrm{H}_{2} \mathrm{O}$ at $25^{\circ} \mathrm{C}$ and $\mathrm{I}$ bar total pressure 
Arsenic in nature. Arsenic abides in $-3,0,+3$ and +5 oxidation states. Arsenious acid (H3AsO3), arsenic acid (H3AsO4), arsenates, methyl arsenic acid, dimethyl arsenic acid, and arsenic etc. are some of the environmental form of arsenic. Inorganic form of arsenic most often exist in water supplies (Bodek et al. 1998). The most common form of arsenic found in natural water is arsenious acid and arsenates (H2AsO4- and HAsO42-) also called as arsenic (III) and $\operatorname{arsenic}(\mathrm{V})$.

Redox potential (Eh) and $\mathrm{pH}$ are the two important regulation factors of arsenic speciation (Fig. 1). (Brookins 1988 and Yan et al. 2000). Under the oxidizing condition $\mathrm{H}_{2} \mathrm{AsO}_{4}{ }^{-}$is dominant at low $\mathrm{pH}$ (less than about $\mathrm{pH} 6$ ) whereas under the higher $\mathrm{pH}$ $\mathrm{HAsO}_{4}{ }^{2-}$ became dominant. $\mathrm{AsO}_{4}{ }^{3-}$ and $\mathrm{H}_{3} \mathrm{AsO}_{4}$ can be present at extremelyhigh and low pHs, respectively. The dissociation of arsenious acid and arsenic acid is given in Fig. 2.

$$
\begin{aligned}
& \mathrm{H}_{3} \mathrm{AsO}_{3} \underset{\mathrm{pK}_{\mathrm{a}}=9.1}{\stackrel{-\mathrm{H}^{+}}{\longrightarrow}} \mathrm{H}_{2} \mathrm{AsO}_{3} \stackrel{-\mathrm{HK}_{\mathrm{a}}=12.1}{\longrightarrow} \mathrm{HAsO}_{3}{ }^{2-} \underset{\mathrm{pK}_{\mathrm{a}}=13.4}{\stackrel{-\mathrm{H}^{+}}{\longrightarrow}} \mathrm{AsO}_{3}{ }^{3-} \\
& \mathrm{H}_{3} \mathrm{AsO}_{4} \underset{\mathrm{pk}_{\mathrm{a}}=2.1}{\stackrel{-\mathrm{H}^{+}}{\longrightarrow}} \mathrm{H}_{2} \mathrm{AsO}_{4} \underset{\mathrm{pk}_{\mathrm{a}}=6.7}{\stackrel{-\mathrm{H}^{+}}{\longrightarrow}} \mathrm{HAsO}_{4}{ }^{2-} \underset{\mathrm{pK}_{\mathrm{a}}=11.2}{\stackrel{-\mathrm{H}^{+}}{\longrightarrow}} \mathrm{AsO}_{4}{ }^{3-}
\end{aligned}
$$

Allophanes are the aluminum silicate with various compositions and are the mail component of the volcanic ash and pumice (Wada et al.1974). In 1976 Henmi and Wada for the first time reported the definite morphology of allophane. Henmi et al. (1976) separated allophane from the volcanic ash and weathered pumice grains and found a hollow spherical morphology. Nano-ball having diameter of $5 \mathrm{~nm}$ and chemical composition from 0.5 to 1.0 with respect to $\mathrm{Si} / \mathrm{Al}$ atomic ratio. Thus allophane is also referred as nano-ball allophane because of its size and hollow spherical morphology.

The ability of andisols to adsorb heavy metals specifically has been reported by many authors (Forbes 1976; Abd-Elfattah 1981). However, they use whole soil or clay fraction $(<2 \mu \mathrm{m})$ as sample. In the present study an attempt is being made to study the adsorption of toxic arsenic on nano-ball allophane.

\section{Materials and methods}

\subsection{Allophane sample preparation}

The allophane sample used in the present study was separated from weathered pumice grains. The pumice sample was collected from Kurayoshi, Tottori prefecture and hence called KyP. To eliminate the possible contamination of allophane sample with volcanic glasses, silica and imogolite proper care was taken while separating fine clay $(<0.2 \mu \mathrm{m})$ from inner part of pumice grain. The separation was proceeding by ultrasonification at $28 \mathrm{KHz}$ and then dispersion at pH4 for low $\mathrm{Si} / \mathrm{Al}$ ratio sample (Henmi and Wada 1976).

The dispersed sample was flocculated by NaClsolution, followed by washing with water to remove excess salts. Some amount of sample was freeze dried and then subjected to infra-red spectroscopy, thermal analysis and chemical analysis to ascertain the purity of the sample. The results confirmed that the sample is free from impurities. Atomic arrangements near the defect (pore) of hollow sphere nano-ball allophane are shown in Fig. 3.

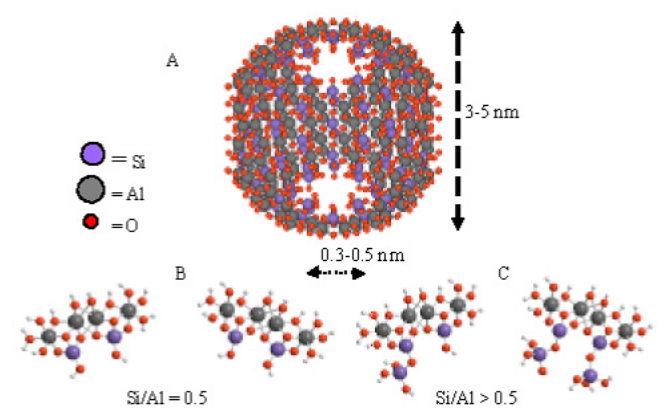

Fig.3. Chemical structure of nano-ball allophane (A) Full structure, (B) and (C) Atomic arrangement in cross section at pore region

\subsection{Arsenateadsorption experiment}

Arsenate adsorption experiment was conductedby treating $5 \mathrm{ml}$ of suspension containing $50 \mathrm{mg}$ of allophane sample with $100 \mathrm{ml}$ aqueous solution of di-sodium hydrogen arsenate heptahydrate $\left(\mathrm{Na}_{2} \mathrm{HAsO}_{4} \cdot 7 \mathrm{H}_{2} \mathrm{O}\right)$ at different concentrationsranging from $0-100 \mu \mathrm{M}$. The initial $\mathrm{pH}$ was kept at 5 under $10 \mathrm{mM} \mathrm{NaCl}$ as a background solution. The mixture was shaken for $24 \mathrm{hrs}$ at room temperature and then centrifuged at $7500 \mathrm{rpm}$ for $30 \mathrm{~min}$. The clear supernatant was collected and is used further for measuring the equilibrium $\mathrm{pH}$ and concentrations of $\mathrm{Si}, \mathrm{Al}$ and As using the polarized atomic absorption spectrophotometer (Hitachi Z-5000). The amount of arsenate adsorbed was calculated from the difference between initial and equilibrium arsenate concentrations, which was expressed in $\mu \mathrm{mol} / \mathrm{g}$.

The adsorption data were plotted according to Langmuir equation.

$$
\mathrm{X}=\frac{\mathrm{Xm} \mathrm{KC}}{1+\mathrm{KC}}
$$

Where:

X- the amount adsorbed per unit mass of allophane sample $(\mu \mathrm{mol} / \mathrm{g})$,

$\mathrm{K}$ - the constant related to the binding energy (L/ $\mu \mathrm{mol})$, 
$\mathrm{C}-\quad$ the equilibrium concentration of absorbate $(\mu \mathrm{mol} / \mathrm{L})$,

$\mathrm{Xm}-\quad$ the maximum adsorption $(\mu \mathrm{mol} / \mathrm{g})$.

The Langmuir equation is further expanded and discussed in later paragraphs.

\section{Results and Discussion}

\subsection{Adsorption isotherm}

The adsorption isotherm for arsenate on KyP sample was given in Fig. 4. The isotherm reveals that the adsorption of arsenate increases with the initial concentration of arsenateat $\mathrm{pH} 5$. The increase is steep at lower equilibrium arsenate concentration, and then the curve gradually became plateau at higher equilibrium arsenate concentration. However, although not presented in the Fig. 4, further increase in equilibrium arsenate concentration above $20 \mu \mathrm{M}$ caused irregular increase in the amount of arsenate adsorption. This may be attributed to the destruction or dissolution of allophane due to excess amount of arsenate in solution. This results in the formation of a new Al-OH or $\mathrm{Al}-\mathrm{OH}_{2}$ at the broken edge. Therefore, only the adsorption data until plateau region were used for further analysis

$\mathrm{Al}-\mathrm{OH}$ and/or $\mathrm{Al}-\mathrm{OH}_{2}$ are responsible for the arsenate adsorption in soil and clay minerals (Parfitt 1979). Since KyP sample has higher content of $\mathrm{Al}$ $(\mathrm{OH})\left(\mathrm{OH}_{2}\right)$ group in the structure and because KyP has lower $\mathrm{Si} / \mathrm{Al}$ ratio or greater $\mathrm{Al}$ atom contents per unit mass the adsorption of arsenate is higher. In the structure of allophane those groups are only located at the pores of the wall of hollow spherules (nano-ball) (Henmi and Huang1985). It was reported earlier that the $\mathrm{pH}$ of equilibrium solution affects the amount of phosphate adsorbed on allophanic clays (Gunjigake and Wada 1981; Nanzjo 1988).

\subsection{Langmuir adsorption equation}

When the arsenate adsorption data in Fig. 4 was plotted according to Langmuir adsorption equation, two straight lines were obtained up to equilibrium concentration of $14.9 \mu \mathrm{M}$ (Fig. 5). Two straight lines with a break at $0.5 \mu \mathrm{M}$ of the equilibrium arsenate concentration were found. An assumption was made that there are two sites responsible for the arsenate adsorption (site I and site II) in allophane sample. Syres et al. (1973) also obtained two straight lines in their Langmuir plot for phosphate adsorption on soils, and they indicated the presence of two sites having widely differing affinity. Thus we rewrote the usual Langmuir equation as two terms Langmuir equation accordingly.

$$
\mathrm{X}=\frac{\mathrm{Xm}^{\mathrm{I}} \mathrm{K}^{\mathrm{I}} \mathrm{C}}{1+\mathrm{K}^{\mathrm{I} C}}+\frac{\mathrm{Xm}^{\mathrm{II}} \mathrm{K}^{\mathrm{II}} \mathrm{C}}{1+\mathrm{K}^{\mathrm{II}} \mathrm{C}}
$$

Where:

$\mathrm{X}$ - theamount of arsenate adsorbed,

$\mathrm{K}-\quad$ a constant related to binding energy,

$\mathrm{Xm}$ - maximum adsorption of arsenate on allophane,

$\mathrm{C}-\quad$ the equilibrium arsenate concentration.

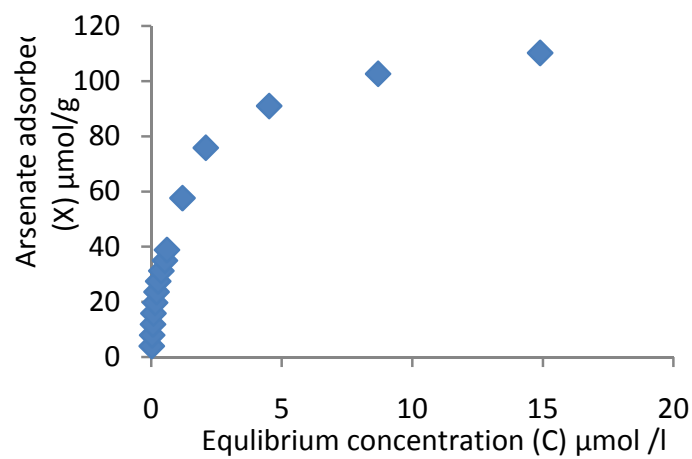

Fig.4. Adsorption isotherm of arsenate on nano-ball allophane

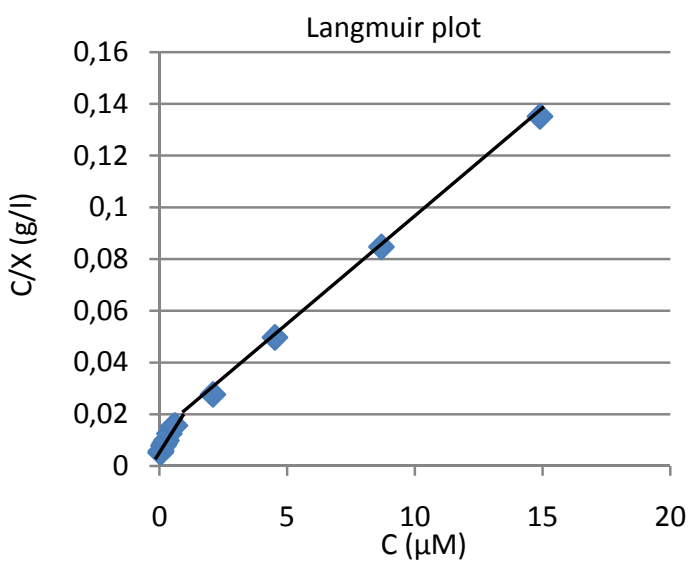

Fig.5. Langmuir plot for the adsorption of arsenate on nano-ball allophane. $C$; equilibrium concentration $(\mu M), X$; amount of adsorption $(\mu \mathrm{mol} / \mathrm{g})$

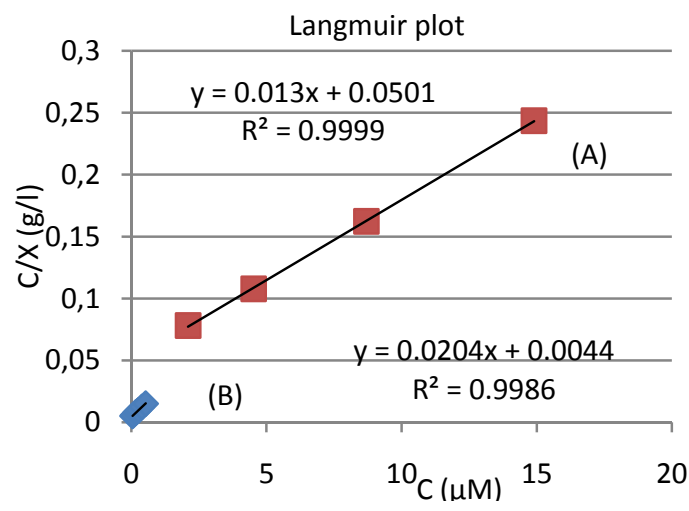

Fig.6. Langmuir plot for the adsorption of arsenate on nano-ball allophaneafter separation to sites I and II.(A) plot for site II after $X^{I}$ was subtracted from each of the Cvalues for the data points in site II and $(B)$ isotherm for siteI 
The superscript I and II refers to the site I and site II respectively. The $\mathrm{Xm}^{\mathrm{I}}$ and $\mathrm{K}^{\mathrm{I}}$ values were calculated from the data at lower $\mathrm{C}$ values to the break point assuming it as site I for the arsenate adsorption. $\mathrm{X}^{\mathrm{I}}$ was calculated for all $\mathrm{C}$ values. The $\mathrm{X}^{\mathrm{II}}$ was calculated by subtracting $\mathrm{X}^{\mathrm{I}}$ from $\mathrm{X}$ at each $\mathrm{C}$ values, then $\mathrm{Xm}^{\mathrm{II}}$ and $\mathrm{K}^{\mathrm{II}}$ was calculated. The data was re- plotted with two sites I and II (Fig. 6) and the maximum adsorption and binding energy values were calculated according to the Fig. $6: \mathrm{Xm}^{\mathrm{I}}=49.01$ $\mu \mathrm{mol} / \mathrm{g}$ and $\mathrm{K}^{\mathrm{I}}=4.63(\mu \mathrm{M})^{-1}$ for site $\mathrm{I}$ whereas $\mathrm{Xm}^{\mathrm{II}}=76.92 \mu \mathrm{mol} / \mathrm{g}$ and $\mathrm{K}^{\mathrm{II}}=0.25(\mu \mathrm{M})^{-1}$ for site II (Table 1).

Table 1.

Adsorption maxima (Xm) and binding energy constant (K) for two sites I and II each described by linear Langmuir plots

\begin{tabular}{|c|c|c|c|c|c|c||}
\hline \multirow{2}{*}{ Adsorbent } & \multicolumn{2}{|c|}{ Site I* } & \multicolumn{2}{|c|}{ Site II } & \multirow{2}{*}{$\mathrm{Xm}^{\mathrm{II}} / \mathrm{Xm}^{\mathrm{I}}$} & \multirow{2}{*}{$\mathrm{K}^{\mathrm{I}} / \mathrm{K}^{\mathrm{II}}$} \\
\cline { 2 - 5 } & $\mathrm{Xm}^{\mathrm{I}}$ & $\mathrm{K}^{\mathrm{I}}$ & $\mathrm{Xm}^{\mathrm{II}}$ & $\mathrm{K}^{\mathrm{II}}$ & \\
\hline $\begin{array}{c}\text { Allophane } \\
\text { (KyP) }\end{array}$ & $4 \mathrm{~mol} / \mathrm{g}$ & $(\mu \mathrm{M})^{-1}$ & $\mu \mathrm{mol} / \mathrm{g}$ & $(\mu \mathrm{M})^{-1}$ & & 18.52 \\
\hline
\end{tabular}

*calculated from the data plotted in Fig. 5

${ }^{\#}$ the value of $X^{I}$ was subtracted from each of the $X$ values for the data points in site II and the new regression equation was calculated for $C / X^{I I}$ against $C$ for site II (see Fig.6)

\section{Interpretation}

The adsorption of arsenate on allophane was very similar with the adsorption of phosphate on nano-ball allophane and other soil having two adsorption sites (Johan 1997, Syers 1973). The present result obtained indicate that the isotherm consist of two linear relationship (site I and II) on plotting the data according to convectional Langmuir equation. The interesting finding of the data indicates that site II has relatively high arsenate adsorption capacity than site I but the binding energy of site I is significantly greater than site II (Table 1). The extensively different $\mathrm{K}$ values obtained for site I and site II of the Langmuir equation educates the possibility that distinct mechanism (probably involving different components) are involved in arsenate sorption. Allophane is known to form aggregates with many unit particles, creating outer and inner surface on and in the aggregates (Wada, 1989). It is conceivable that the aluminol groups, Al-OH and $\mathrm{Al}-\mathrm{OH}_{2}$ are responsible for the arsenate adsorption. Arsenate reacts with aluminol group inside the aggregate (site I) because this site has greater adsorption energy, then after saturating site I arsenate react with aluminol group at the outer surface of allophane (site II)

\section{Conclusion}

The sorption of arsenate was successfully represented by linear Langmuir isotherm with two sites (I and II). The inner surface of allophane aggregate may correspond to the site I while the outer surface on the aggregates may correspond to the site II for the arsenate sorption.

The environmental toxic level of arsenate is $0.6 \mu \mathrm{M}$, and from our experiment it was found that the initial arsenate concentration up to $10 \mu \mathrm{M}$ was decreased to below the toxic level. However higher arsenate concentration in the aqueous solution (more than $15 \mu \mathrm{M}$ ) causes partial dissolution of chemical structure of allophane. Hence allophane or composite material containing allophane can be a good adsorbent at the final stage of treatment of waters containing arsenate.

\section{References}

Abd-Elfattah, A. and Wada, K. (1981) Adsorption of lead, copper, zinc, cobalt, and cadmium by soils that differ in cation exchange material. Journal of Soil Science, 32, 271-283. http://dx.doi.org/10.1111/j.13652389.1981.tb01706.x

Bodek, I., Lyman, W. J., Reehl, W. F. and Rosenblatt, D. H.: Environmental inorganic chemistry: Properties, precesses and estimation methods, Pergamon Press, U.S.A; 1998.

Brookins, D. G, 1988. Eh- $\mathrm{pH}$ Diagrams for Geochemistry. Springer-Verlag, Berlin. http://dx.doi.org/10.1007/978-3-642-73093-1

Forbes, E. A., Posner, A. M. and Quirk, J. P. (1976) The specific adsorption of divalent $\mathrm{Cd}, \mathrm{Co} . \mathrm{Cu}, \mathrm{Pb}$, and $\mathrm{Zn}$ on goelite. Journal of soil science, 28, 154-166. http://dx.doi.org/10.1111/j.1365-2389.1976.tb01986.x

Gunjigake, N. and Wada, K. (1981) Effects of Phosphorous concentration and $\mathrm{pH}$ on phosphate retention by active aluminum and iron of Ando soils. Soil Science, $\quad 132, \quad 347-352$. http://dx.doi.org/10.1097/00010694-198111000-00004

Henmi, T. and Huang, P. M. (1985) Removal of phosphorous by poorly ordered clay as influenced by heating and grinding. Applied Clay Science., 1, 133-144. http://dx.doi.org/10.1016/0169-1317(85)90569-1

Henmi, T. and Wada, K. (1976) Morphology and composition of allophane. American Mineralogist, 61, 370-390.

Johan, E., Matsue, N. and Henmi, T. (1997) Phosphate adsorption on nano-ball allophane and its molecular orbital analysis. Clay Science, 10, 259-270.

Mackenzie, E. T., Lamtzy, R. J. and Petorson, V. (1979) Global trace metals cycles and predictions. 
Journal of the International Association for Mathematical Geology, 6 , 99-142. http://dx.doi.org/10.1007/BF01028961

Mandal, B. K. and Suzuki, K. T. (2002) Arsenic around the world: a review; Talanta, 58, 201-235. http://dx.doi.org/10.1016/S0039-9140(02)00268-0

Nanzyo, M. (1988) Phosphate sorption on the clay fraction of Kanuma pumice. Clay Science, 7, 89-96.

Parfitt, R. L. (1979) Anion adsorption by soils and soils materials. Advances in Agronomy, 30, 1-50. http://dx.doi.org/10.1016/S0065-2113(08)60702-6

Syres, J.K., Brownman, M.G., Smillie, G.W. and Corey, R.B., (1973) Phosphate sorption by soils evaluated by the Langmuir adsorption equation. Soil Sci. Am. Proc., 37, 358-363. http://dx.doi.org/10.2136/sssaj1973.03615995003700030 $015 \mathrm{x}$

Wada, K (1989) allophane and imogolite.In Minerals of Soil Environment ( $2^{\text {nd }}$ ed.), Eds. Dixon, J. B. and Weed, S. B., p.1051-1088. Soil Sci. Soc. Am., Madison.

Wada, K. and Harwaed, M. E. (1974) Amorphous clay constituents in soil. Advances in Agronomy, 26 211260. http://dx.doi.org/10.1016/S0065-2113(08)60872-X

Yan, X.-P., Kerrich, R. and Hendry, M. J. (2000) Distribution of arsenic (III), arsenic (V) and total inorganic arsenic in pore waters from a thick till and clay-rich aquitard sequence, Saskatchewan, Canada. Geochem.Cosmochim. Acta, 4, 2637-2648. http://dx.doi.org/10.1016/S0016-7037(00)00380-X
Mr. Elvis Anup Shukla, PhD ScholarUnited Graduate School of Agricultural Science, Ehime University.

Main research area: Allophane, Zeolite, arsenic adsorption, water reclamation, adsorption experiments.

Address: Ehime University 3-5-7 Tarumi, Matsuyama, Japan. 790-8566

Tel.: +81 (0) 90-2895-7494

E-mail: elvisshukla@gmail.com

Dr. Naoto Matsue, Associate Professor Laboratory of Applied Chemistry for Environmental Industry Faculty of Agriculture, Ehime University.

Main research area: Soil chemistry, clay minerals, zeolites, nano-ball allophane, computational chemistry, structural chemistry, adsorption, purification, cation exchange.

Address: Ehime University 3-5-7 Tarumi, Matsuyama, Japan. 790-8566

Tel.: $\quad$ +81 (0) 89-946-9844

Dr. Teruo Henmi, Professor Laboratory of Applied Chemistry for Environmental Industry Faculty of Agriculture, Ehime University.

Main research area: Functional Nanomaterials, nano-ball allophane, nanotube immogolite, artificial zeolite and synthetic zeolites, clay minerals, amorphous aluminum silicate, circular earth resources, biological renewable resources, biomass.

Address: Ehime University 3-5-7 Tarumi, Matsuyama, Japan. 790-8566

Tel.: $\quad+81(0)$ 89-946-9843

Dr Erni Johan, Post Doctor researcher at Laboratory of Applied Chemistry for Environmental Industry Faculty of Agriculture, Ehime University.

Main research area: Nano-ball allophane, artificial zeolite, Nano zeolite, phosphate adsorption, zeolite synthesis from rice husk.

Address: Ehime University 3-5-7 Tarumi, Matsuyama, Japan. 790-8566

Tel.: $\quad+81(0)$ 89-946-9681 